\title{
An Experimental Study to find out the Additive Analgesic Effect of Hydro-Alcoholic Extract of Ginger with Paracetamol and Ibuprofen in Management of Pain in Mice
}

\author{
Dr. Amit Kumar Ghosh ${ }^{1}$, Dr. Subrata Das ${ }^{2}$, Dr. Mausumi De ${ }^{3 *}$ \\ ${ }^{1}$ Associate Professor, Pharmacology. R.G.Kar Medical College, Kolkata, India \\ ${ }^{2}$ Final Year Post Graduate Student, Pharmacology, R.G.Kar Medical College, Kolkata, India \\ ${ }^{3}$ Associate Professor, Pharmacology. R.G.Kar Medical College, Kolkata, India
}

\author{
DOI: $10.36348 /$ sjmps.2020.v06i01.001 \\ | Received: 20.12.2019 | Accepted: 31.12.2019 | Published: 06.01.2020 \\ *Corresponding author: Dr. Mausumi De
}

\section{Abstract}

Present study was carried out on adult Swiss albino mice of both sex, consisting of six groups with six mice in each group to find out additive analgesic effect of Hydro-alcoholic extract of Ginger with Paracetamol and also to find out additive analgesic effect of Hydro-alcoholic extract of Ginger with Ibuprofen by hot plate and tail flick methods. These six groups were, Groups-A paracetamol, group-B was Ibuprofen, group-C was distilled water, group-D (Hydro-alcoholic extract of Ginger, group-E (Paracetamol + Hydro-alcoholic extract of Ginger), and group-F (Ibuprofen + Hydro-alcoholic extract of Ginger). We find that Paracetamol, ibuprofen has analgesic effect of their own on mice but we did not find any significant analgesic effect of Ginger on mice in singly or additive analgesic effect in combination with ibuprofen or paracetamol. So, we may conclude that Ginger has no additive analgesic effect and no analgesic effect on single use also. Keywords: Ginger, analgesic, additive, paracetamol, ibuprofen, mice.

\footnotetext{
Copyright @ 2020: This is an open-access article distributed under the terms of the Creative Commons Attribution license which permits unrestricted use, distribution, and reproduction in any medium for non-commercial use (NonCommercial, or CC-BY-NC) provided the original author and source are credited.
}

\section{INTRODUCTION}

Pain as an unpleasant sensory or emotional experience associated with tissue damage. I.A.S.P. committee for Taxonomy defined pain as "an unpleasant sensory or emotional experience associated with actual or potential tissue damage, or describe in terms of such damage [1]". Pain is the most common reason for individuals to seek medical care [2].

Pain motivates the individual to withdraw from damaging situations, to protect a damaged body parts while it heals, and to avoid similar experiences in the future. . Sometimes pain may arise in the absence of any detectable stimulus, damage or disease [3].

Analgesics are drugs that selectively relieve the pain by acting in the CNS or on peripheral pain pathway, without significantly altering consciousness [4]. Analgesic is divided into two groups, Opioids \& non-opioids NSAIDs (non-steroidal anti-inflammatory drugs).

Inflammation means pain, redness, swelling and heat that usually developed in response to injury.
The management of acute and chronic pain is important for the patient's wellbeing. Though opioids analgesic like morphine, pethidine is good painkiller but they have abuse potential and lots of side effects may occur such as respiratory depression, tolerance and dependence etc [5]. Non-steroidal anti-inflammatory drugs(NSAIDS) are also good analgesic but also have many adverse effect like hypersensitivity reaction, hepatic damage (Reye's syndrome), acid peptic disorder, gastric ulcer, neuropathy, hemolytic anemia etc $[6,7]$. The choice of analgesics for acute pain depends on the efficacy, side effects, complications, pharmacokinetics and its cost-effectiveness etc [8].

Ginger (Zingiber Officinale) is a flowering plant. Its rhizome or ginger root is called ginger $[9,10]$. It is widely used as a spice all over the world and also use as a folk medicine [11]. It is presumed that Ginger has some medicinal property such as analgesic, antiinflammatory, hypoglycemic, Anti-oxidant, Antiemetic, Anti-tumorigenic effect [12]. Few research works was published on concomitant use of ginger with NSAIDs (Paracetamol and Ibuprofen) in management of pain. Study also showed that ginger (Zingiber 
officinale) rhizomes Hydro-alcoholic extract possesses analgesic, anti-inflammatory and hypoglycaemic properties [13].

In some diseased condition of kidney (such as renal failure), heart (cardiac failure, myocardial infarction, hypertension), liver (hepatic failure), GI tract disorders (gastric Ulcer) dose reduction of NSAID is required and this reduce doses also decrease the analgesic effect of NSAID [14-16]. If we find that Ginger may have additive analgesic effect with these two NSAID (paracetamol or Ibuprofen), we may use this two commonly used NSAID effectively and safely for longer periods in reduced doses with low risk of adverse effects.

In this study we have used two types of NSAIDs (paracetamol and Ibuprofen). Paracetamol is a centrally acting analgesic and Ibuprofen is a peripherally acting analgesic [17, 18]. By using two types of NSAIDS we want to find out whether additive analgesic effect of Ginger is due to central and/or peripheral effect.

\section{OBJECTIVES}

Primary objectives

To find outt additive analgesic effect of Ginger in concomitant use with Paracetamol or Ibuprofen in management of pain in mice

\section{Secondary objectives}

To find out the analgesic effect of Ginger extract if present acting either centrally or peripherally.

\section{MATERIAL AND METHODS}

Type of study: Animal experimental study. Study Duration: From April 2017 to September 2018. Place of study- Department of Pharmacology, R.G.Kar Medical College, Kolkata, India.

Sample Size: 36 adult Swiss albino mice

Study Tool: 36 albino mice weighing about $25 \mathrm{gm}$, hot plate apparatus, and tail flick apparatus.

\section{Ethical permission}

\section{Necessary permission was taken from the Institutional Animal Ethics}

Committee and study was performed following the guidelines of the Committee for the Purpose of Control and Supervision on Experiments on Animals (CPCSEA), Animal Welfare division, Ministry of Environment, Govt. of India. The care and use of the laboratory animals were strictly followed throughout the experimental procedure.

Procedure: - In this study we used adult Swiss albino mice weight $25 \pm 2$ gm [19]. Mice were divided into Six groups and in each group there are six mice. The groups are as follows:-

Group- A= 6 mice (For Paracetamol)

Group- $B=6$ mice (For Ibuprofen)

Group- $\mathrm{C}=6$ mice (For control, treat with Distilled water)

Group- D = 6 mice (For Hydro-alcoholic extract of Ginger)

Group- E = 6 mice (For Paracetamol+ Hydro-alcoholic extract of Ginger)

Group- $\mathrm{F}=6$ mice (For Ibuprofen+ Hydro-alcoholic extract of Ginger)

Calculation of dose of drugs:-Dose of drug for mice was calculated by dose conversion from human dose to mouse dose. From human dose to mouse dose conversion factor is 12.3 [20].

Calculation of dose of mouse (weight $=25$ gm):-Paracetamol dose for human= $15 \mathrm{mg} / \mathrm{Kg}$. per oral. So, Paracetamol dose for mouse $=(15 \times 12.3)=$ $184.5 \mathrm{mg} / \mathrm{Kg}$. Now, $184.5 \mathrm{mg} / \mathrm{Kg}$ rounded off to 185 $\mathrm{mg} / \mathrm{Kg}$. So, Paracetamol dose for mouse (weight $=25$ $\mathrm{gm})=(185 \times 25) / 1000=4.62 \mathrm{mg}$. in this way we calculated the dose of ibuprofen was $3 \mathrm{mg}$ for a mouse weighing $25 \mathrm{gm}$. and $20 \mathrm{mg}$ Hydro-Alcoholic extract of Ginger $(800 \mathrm{mg} / \mathrm{kg})$.

Two types of tests were done, (Hot plate and Tail flick) to study of analgesic effect of drugs. Test reading were taken at intervals of 20 minutes, 60 minutes and 90 minutes as per standard protocol. Then data were compared by statistical analysis to obtain the result. Firstly, data of Paracetamol , Ibuprofen and Ginger treated groups were compared with control (distilled water) group to show there analgesic effects individually, then data of paracetamol treated group were compared with data obtained from paracetamol + Ginger treated group and data of Ibuprofen treated group were compared with data obtained from Ibuprofen + Ginger treated group to show additive analgesic effects.

\section{RESULTS}

Statistical data N, mean, std. deviation etc. of Hot plate and tail flick method test are given in the table 1 to 10 . 
Table-01: Group Statistics of Hot plate test

\begin{tabular}{|c|l|r|r|c|c|}
\hline Group = A \& C & N & Mean & Std. Deviation & t & P value \\
\hline @20_min Group- A & 6 & 5.1833 & 0.50365 & 10.922 & $0.000^{* * *}$ \\
Group-C & 6 & 2.4000 & 0.36878 & & \\
\hline @60_min Group-A & 6 & 7.0167 & 0.51153 & 19.550 & $0.000^{* * *}$ \\
Group-C & 6 & 2.3333 & 0.28752 & & \\
\hline @90_min Group-A & 6 & 9.0667 & 0.79415 & 19.675 & $0.000^{* * *}$ \\
Group-C & 6 & 2.3833 & 0.24833 & & \\
\hline
\end{tabular}

$*=$ Significant $(\mathrm{P}$ value $<0.05) \quad * *=$ strongly Significant $(\mathrm{P}$ value $<0.01)$

In this Table: - 01 shows that, Group-A (Paracetamol) shows strongly significant analgesic effect (P value < 0.01 ) on mice in all the times (20,60 and $90 \mathrm{~min}$ ) when we compare with Group-C (control).

Table-02: Group Statistics of Tail flick test

\begin{tabular}{|c|l|c|c|c|c|}
\hline Group = A \& C & N & Mean & Std. Deviation & t & P value \\
\hline @20_min Group-A & 6 & 5.3000 & 0.65422 & 9.393 & $0.000^{* *}$ \\
Group-C & 6 & 2.6833 & 0.19408 & & \\
\hline @60_min Group-A & 6 & 7.5333 & 0.68313 & 15.828 & $0.000^{* *}$ \\
Group-C & 6 & 2.7833 & 0.27142 & & \\
\hline @90_min Group-A & 6 & 9.4667 & 0.70899 & 22.168 & $0.000^{* *}$ \\
Group-C & 6 & 2.8000 & 0.20000 & & \\
\hline
\end{tabular}

$*$ * Significant $(\mathrm{P}$ value $<0.05) \quad * *=$ strongly Significant $(\mathrm{P}$ value $<0.01)$

In this Table: - 02 shows that, Group-A (Paracetamol) shows strongly significant analgesic effect (P value < $0.01)$ on mice in all the times $(20,60$ and $90 \mathrm{~min})$ when we compare with Group-C (control).

Table-03: Group Statistics of hot plate test

\begin{tabular}{|c|l|l|r|c|c|}
\hline Group = B \& C & N & Mean & Std. Deviation & t & P value \\
\hline @ 20_min Group-B & 6 & 6.0333 & 0.72847 & 10.900 & $0.000^{* *}$ \\
Group-C & 6 & 2.4000 & 0.36878 & & \\
\hline @60_min Group-B & 6 & 8.3167 & 0.48751 & 25.895 & $0.000^{* *}$ \\
Group-C & 6 & 2.3333 & 0.28752 & & \\
\hline @90_min Group-B & 6 & 10.1500 & 0.87579 & 20.899 & $0.000^{* * *}$ \\
Group-C & 6 & 2.3833 & 0.24833 & & \\
\hline
\end{tabular}

In this Table: - 03 shows that, Group-B (Ibuprofen) shows strongly significant analgesic effect (P value $<0.01$ ) on mice in all the times (20,60 and $90 \mathrm{~min}$ ) when we compare with Group- C (control).

Table-04: Group Statistics of Tail flick test

\begin{tabular}{|cc|c|c|c|c|c|}
\hline \multicolumn{2}{|c|}{ Group = B \& C } & N & Mean & Std. Deviation & t & P value \\
\hline @ 20_min & Group-B & 6 & 6.6500 & 0.39875 & 21.910 & 0.000 \\
& Group-C & 6 & 2.6833 & 0.19408 & & \\
\hline \multirow{2}{*}{ 60_min } & Group-B & 6 & 9.0167 & 0.62423 & 22.431 & $0.000^{* * *}$ \\
& Group-C & 6 & 2.7833 & 0.27142 & & \\
\hline \multirow{2}{*}{ @90_min } & Group-B & 6 & 10.8667 & 0.85245 & 22.567 & 0.000 \\
& Group-C & 6 & 2.8000 & 0.20000 & & \\
\hline
\end{tabular}

In this Table: - 04 shows that, Group-B (Ibuprofen) shows strongly significant analgesic effect (P value $<0.01)$ on mice in all the times (20,60 and $90 \mathrm{~min})$ when we compare with Group-C (control).

Table-05: Group Statistics of hot plate test

\begin{tabular}{|cc|l|c|c|c|c|}
\hline \multicolumn{2}{|c|}{ Group = D \& C } & N & Mean & Std. Deviation & t & P value \\
\hline @ 20_min Group-D & 6 & 2.4500 & 0.32711 & 0.248 & 0.809 \\
& Group-C & 6 & 2.4000 & 0.36878 & & \\
\hline @60_min & Group-D & 6 & 2.3167 & 0.19408 & -0.118 & 0.909 \\
& Group-C & 6 & 2.3333 & 0.28752 & & \\
\hline @90_min & Group-D & 6 & 2.3667 & 0.38816 & -0.089 & 0.931 \\
& Group-C & 6 & 2.3833 & 0.24833 & & \\
\hline
\end{tabular}


In this Table: - 05 shows that, Group-D (Ginger) has no significant analgesic effect $(\mathrm{P}$ value $>0.05)$ on mice in all the times (20,60 and $90 \mathrm{~min})$ when we compare with Group C (control).

Table-06: Group Statistics of Tail flick test

\begin{tabular}{|c|l|c|c|c|l|}
\hline Group = D \& C & N & Mean & Std. Deviation & t & P value \\
\hline @ 20_min Group- D & 6 & 2.7000 & 0.14142 & 0.170 & 0.868 \\
Group- C & 6 & 2.6833 & 0.19408 & & \\
\hline @60_min Group- D & 6 & 2.7667 & 0.34448 & -0.093 & 0.928 \\
Group- C & 6 & 2.7833 & 0.27142 & & \\
\hline @90_min Group- D & 6 & 2.8167 & 0.24833 & 0.128 & 0.901 \\
Group- C & 6 & 2.8000 & 0.20000 & & \\
\hline
\end{tabular}

$*=$ Significant $(\mathrm{P}$ value $<0.05) \quad * *=$ strongly Significant $(\mathrm{P}$ value $<0.01)$

In this Table: - 06 shows that, Group-D (Ginger) has no significant analgesic effect ( $\mathrm{P}$ value $>0.05)$ on mice in all the times (20,60 and $90 \mathrm{~min})$ when we compare with Group C (control).
7) Statistical data (N, mean, std. deviation, etc) of Hot plate test of Group-A (Paracetamol) and Group$\mathrm{E}$ (Paracetamol + Ginger) are given in the table :-07.

Table-07: Group Statistics of hot plate test

\begin{tabular}{|c|c|c|c|c|c|}
\hline Group $=$ A \& E & $\mathbf{N}$ & Mean & Std. Deviation & $\mathbf{t}$ & P value \\
\hline $\begin{array}{cc}\text { @20_min } & \begin{array}{c}\text { Group-A } \\
\text { Group-E }\end{array}\end{array}$ & $\begin{array}{l}6 \\
6\end{array}$ & $\begin{array}{l}5.1833 \\
5.3000\end{array}$ & $\begin{array}{l}0.50365 \\
0.64498\end{array}$ & -0.349 & 0.734 \\
\hline $\begin{array}{cc}\text { @ 60_min } & \begin{array}{c}\text { Group-A } \\
\text { Group-E }\end{array} \\
\end{array}$ & $\begin{array}{l}6 \\
6 \\
\end{array}$ & $\begin{array}{l}7.0167 \\
6.9833 \\
\end{array}$ & $\begin{array}{l}0.51153 \\
0.82077 \\
\end{array}$ & 0.084 & 0.934 \\
\hline $\begin{array}{c}\text { @ 90_min } \begin{array}{l}\text { Group-A } \\
\text { Group-E }\end{array} \\
\text { Grous }\end{array}$ & $\begin{array}{l}6 \\
6\end{array}$ & $\begin{array}{l}9.0667 \\
9.1833\end{array}$ & $\begin{array}{l}0.79415 \\
0.85654\end{array}$ & -0.245 & 0.812 \\
\hline
\end{tabular}

$*=$ Significant $(\mathrm{P}$ value $<0.05) \quad * *=$ strongly Significant $(\mathrm{P}$ value $<0.01)$

In this Table:- 07 shows that, Group- E (Paracetamol + Ginger) shows no additive analgesic effect ( $\mathrm{P}$ value > 0.05 ) on mice in all the times ( 20,60 and 90 min ) when we compare with Group- A (Paracetamol).

Table-08: Group Statistics of Tail flick test

\begin{tabular}{|ll|l|c|c|c|l|}
\hline \multicolumn{2}{|c|}{ Group = A \& E } & N & Mean & Std. Deviation & t & P value \\
\hline @20_min & Group-A & 6 & 5.3000 & 0.65422 & 0.049 & 0.962 \\
Group-E & & 6 & 5.3167 & 0.51929 & & \\
\hline @60_min & 6 & 7.5333 & 0.68313 & 0.043 & 0.967 \\
Group-A & Group-E & 6 & 7.5500 & 0.67454 & & \\
\hline @90_min & 6 & 9.4667 & 0.70899 & 0.041 & 0.968 \\
Group-A & Group-E & 6 & 9.4500 & 0.70922 & & \\
\hline \multicolumn{7}{|c|}{$*$ * Significant (P value < 0.05) strongly Significant (P value < 0.01) }
\end{tabular}

In this Table:- 08 shows that, Group- E (Paracetamol + Ginger) shows no additive analgesic effect (P value > 0.05) on mice in all the times (20,60 and 90 min ) when we compare with Group- A (Paracetamol).

Table-09: Group Statistics of hot plate test

\begin{tabular}{|c|c|c|c|c|c|}
\hline Group = B \& F & N & Mean & Std. Deviation & t & P value \\
\hline @20_min Group-B & 6 & 6.0333 & 0.72847 & -0.215 & 0.834 \\
Group-F & 6 & 6.1000 & 0.21909 & & 0.888 \\
\hline @60_min Group-B & 6 & 8.3167 & 0.48751 & -0.144 & \\
Group-F & 6 & 8.3500 & 0.28810 & & 0.926 \\
\hline @90_min Group-B & 6 & 10.1500 & 0.87579 & -0.095 & \\
Group-F & 6 & 10.2000 & 0.94234 & & \\
\hline
\end{tabular}

$*=$ Significant $(\mathrm{P}$ value $<0.05) \quad * *=$ strongly Significant $(\mathrm{P}$ value $<0.01)$

In this Table:- 09 shows that, Group- F (Ibuprofen + Ginger) shows no additive analgesic effect (P value > 0.05 ) on mice in all the times ( 20,60 and $90 \mathrm{~min}$ ) when we compare with Group- B (Ibuprofen). 
Amit Kumar Ghosh et al; Saudi J Med Pharm Sci, Jan., 2020; 6(1): 1-6

Table-10: Group Statistics of Tail flick test

\begin{tabular}{|l|l|c|c|c|c|}
\hline Group = B \& F & N & Mean & Std. Deviation & t & P value \\
\hline @20_min Group-B & 6 & 6.6500 & 0.39875 & 0.124 & 0.904 \\
Group-F & 6 & 6.6167 & 0.52694 & & 0.784 \\
\hline @60_min Group-B & 6 & 9.0167 & 0.62423 & -0.282 & \\
Group-F & 6 & 9.1167 & 0.60470 & & 0.918 \\
\hline @90_min Group-B & 6 & 10.8667 & 0.85245 & -0.106 & \\
Group-F & 6 & 10.9167 & 0.77825 & & \\
\hline
\end{tabular}

$*=$ Significant $(\mathrm{P}$ value $<0.05) \quad * *=$ strongly Significant $(\mathrm{P}$ value $<0.01)$

In the Table: - 10 shows that, Group- F (Ibuprofen + Ginger) shows no additive analgesic effect $(\mathrm{P}$ value $>0.05)$ on mice in all the times (20, 60 and $90 \mathrm{~min})$ when we compare with Group- B (Ibuprofen).

\section{DISCUSSIONS}

Data obtained from hot plate and tail flick study of group-A (paracetamol) and group-C (distilled water) at time interval of 20,60 and $90 \mathrm{~min}$ are compared between these two groups. We find that, $\mathrm{P}$ value is $<0.01$ in all the time. So, from this hot plate study we can say paracetamol has significant analgesic effect on mice [21].

In literature also, it is mentioned that paracetamol is highly selective for central COX2 activities in the brain, which may contribute to its ability to treat fever and pain [22, 23]. This activity does not appear to be direct inhibition by blocking an active site, but rather by reducing $\mathrm{COX}-3$, which must be oxidized in order to function [22].

Data obtained from tail flick and hot plate study of group-B (Ibuprofen) and group-C (distilled water) at time interval of 20,60 and $90 \mathrm{~min}$ are compared between these two groups. We find that, $\mathrm{P}$ value is $<0.01$ in all the time. So, from this study we can say Ibuprofen has significant analgesic effect on mice [24]. Ibuprofen is a non-steroidal antiinflammatory drug (NSAID) drug [25]. It is used for treating pain, fever, and inflammation. So our study also established its pain killing property.

Data obtained from tail flick and hot plate study of group-D (Hydro-alcoholic extract of Ginger) and group-C (distilled water) at time interval of 20, 60 and $90 \mathrm{~min}$ are compared between these two groups. We find that, $\mathrm{P}$ value is $>0.05$ in all the time. So, from this hot plate study we can say Ginger has no analgesic effect on mice.

Data obtained from tail flick and hot plate study of group-A (paracetamol) and group-E (Paracetamol + Hydro-alcoholic extract of Ginger) at time interval of 20,60 and $90 \mathrm{~min}$ are compared between these two groups. We find that, $\mathrm{P}$ value is $>0.05$ in all the time. So, from this hot plate study we can say Ginger has no additive analgesic effect on mice and also has no analgesic effect, which we found in the previous discussion [26-28].
Data obtained from hot plate and tail flick study of group-B (Ibuprofen) and group-F (Ibuprofen + Hydro-alcoholic extract of Ginger) at time interval of 20, 60 and $90 \mathrm{~min}$ are compared between these two groups. We find that, $\mathrm{P}$ value is $>0.05$ in all the time. So, from this hot plate study we can say Ginger has no additive analgesic effect on mice and also has no analgesic effect, which we found in the previous discussion [26-28]. In a study Black C.D. et al. found that a single $2 \mathrm{~g}$ dose of ginger does not attenuate eccentric exercise-induced muscle pain, inflammation or dysfunction $45 \mathrm{~min}$ after ingestion. However, ginger may attenuate the day-to-day progression of muscle pain [27].

\section{CONCLUSION}

Ginger has no analgesic effect on single use and Ginger has no additive analgesic effect with Paracetamol and Ibuprofen.

\section{REFERENCES}

1. Anand, K.J., Craig, K.D. (1996). New perspectives on the definition of pain. Pain-Journal of the International Association for the Study of Pain, 67(1),3-6.

2. Mäntyselkä, P., Kumpusalo, E., Ahonen, R., Kumpusalo, A., Kauhanen, J., Viinamäki, H., Halonen, P., Takala, J. (2001). Pain as a reason to visit the doctor: a study in Finnish primary health care. Pain, 89(2-3), 175-80.

3. Stewart, W.F., Ricci, J.A., Chee, E., Morganstein, D., Lipton, R.(2003). Lost productive time and cost due to common pain conditions in the US workforce. Jama, 290(18),2443-54.

4. Raffa, R.B., Friderichs, E.L., Reimann, W.O., Shank,R.P., Codd, E.E., Vaught, J.L.(1992). Opioid and nonopioid components independently contribute to the mechanism of action of tramadol, an atypical opioids analgesic. Journal of Pharmacology and Experimental Therapeutics, 260(1), 275-85.

5. Volkow, N.D., McLellan, A.T.(2016). Opioid abuse in chronic pain-misconceptions and mitigation strategies. New England Journal of Medicine, 374(13), 1253-63. 
6. Pelletier, J.P., Martel-Pelletier, J., Rannou, F., Cooper, C. (2016). Efficacy and safety of oral NSAIDs and analgesics in the management of osteoarthritis: Evidence from real-life setting trials and surveys. In Seminars in arthritis and rheumatism,45(4),22-27

7. Bjarnason, I., Hayllar, J. (1993). Side effects of nonsteroidal anti-inflammatory drugs on the small and large intestine in humans. Gastroenterology, 104(6), 1832-47.

8. Barkin, R.L., Barkin, D.S., Barkin, S.J., Barkin, S.A.(1998). Opiate, opioids, and centrally acting analgesics and drug interactions: the emerging role of the psychiatrist. Medical Update for Psychiatrists, 3(6), 171-5.

9. Cook, M.S. (2016). "Ginger is Better than Drugs for Pain, says Study". http://www.care2.com/greenliving/study.

10. Dosunmu, A., Akinbami, A., Uche, E., Adediran, A., \& John-Olabode, S. (2016). Electrocardiographic study in adult homozygous sickle cell disease patients in Lagos, Nigeria. Journal of tropical medicine, 2016.

11. Srivastava, K.C., Mustafa, T.(1992). Ginger (Zingiber officinale) in rheumatism and musculoskeletal disorders. Medical hypotheses, 39(4),342-8.

12. Grzanna, R., Lindmark, L., Frondoza, C.G.(2005). Ginger - an herbal medicinal product with broad anti-inflammatory actions. Journal of medicinal food, $8(2), 125-32$.

13. Al-Amin, Z.M., Thomson, M., Al-Qattan, K.K., Peltonen-Shalaby, R., Ali, M.(2006). Anti-diabetic and hypo-lipidemic properties of ginger (Zingiber officinale) in streptozocin-induced diabetic rats. British journal of nutrition, 96(4),660-6.

14. Hörl, W.H. (2010). Nonsteroidal anti-inflammatory drugs and the kidney. Pharmaceuticals, 3(7),2291321.

15. Singh, G., Rosen, D.R.(1998). NSAID induced gastrointestinal complications: the ARAMIS perspective--1997. Arthritis, Rheumatism, and Aging Medical Information System. The Journal of rheumatology, 51(s),8-16.

16. Triantafyllou, K., Vlachogiannakos, J., Ladas, S.D.(2010). Gastrointestinal and liver side effects of drugs in elderly patients. Best practice \& research Clinical gastroenterology, 24(2),203-15.

17. Botting, R., Ayoub, S.S. (2005). COX-3 and the mechanism of action of paracetamol/acetaminophen. Prostaglandins, Leukotrienes and Essential Fatty Acid, 72(2),85-7.

18. Vane, J.R., Botting, R.M.(1998). Antiinflammatory drugs and their mechanism of action. Inflammation Research, 47(2),78-87.

19. Bhowmick, R., Sarwar, M.S., RahmanDewan, S.M., Das, A., Das, B., Nasiruddin, M.M., Islam, M.S. (2014). In vivo analgesic, antipyretic, and anti-inflammatory potential in Swiss albino mice and in vitro thrombolytic activity of hydroalcoholic extract from Litsea glutinosa leaves. Biological research, 47(1),56.

20. . Nair, A.B., Jacob, S. A.(2016). Simple practice guide for dose conversion between animals and human. Journal of basic and clinical pharmacy, 7(2), 27.

21. Miranda, H.F., Puig, M.M., Prieto, J.C., Pinardi. G.(2006). Synergism between paracetamol and non-steroidal anti-inflammatory drugs in experimental acute pain. Pain, 121(1-2),22-8.

22. Ghanem, C.I., Pérez, M.J., Manautou, J.E., Mottino, A.D.(2016). Acetaminophen from liver to brain: new insights into drug pharmacological action and toxicity. Pharmacological research, 109,119-31.

23. Dickinson, A.L., Leach, M.C., Flecknell, P.A.(2009). The analgesic effects of oral paracetamol in two strains of mice undergoing vasectomy. Laboratory animals, 43(4),357-61

24. Kolesnikov, Y.A., Wilson, R.S., Pasternak, G.W. (2003). The synergistic analgesic interactions between hydrocodone and ibuprofen. Anesthesia \& Analgesia, 97(6), 1721-3.

25. Rainsford, K.D.(2009). Ibuprofen: pharmacology, efficacy and safety. Inflammo-pharmacology, 17(6),275-342.

26. Raji, Y., Udoh, U.S., Oluwadara, O.O., Akinsomisoye,O.S., Awobajo, O., Adeshoga, K.(2002). Anti-flammatory and analgesic properties of the rhizome extract of zingiber officinale. African Journal of Biomedical Research, $5(3)$.

27. Black, C.D., O'connor ,P.J.(2010). Acute effects of dietary ginger on muscle pain induced by eccentric exercise. Phytotherapy research, 24(11),1620-6.

28. Black, C., O'Connor, P. (2008). Short term effects of 2-grams of dietary ginger on muscle pain, inflammation and disability induced by eccentric exercise. The Journal of Pain, 9(4),25. 